\title{
Ureteropelvic Junction
}

National Cancer Institute

\section{Source}

National Cancer Institute. Ureteropelvic Junction. NCI Thesaurus. Code C106203.

The area where the ureter joins the renal pelvis. 